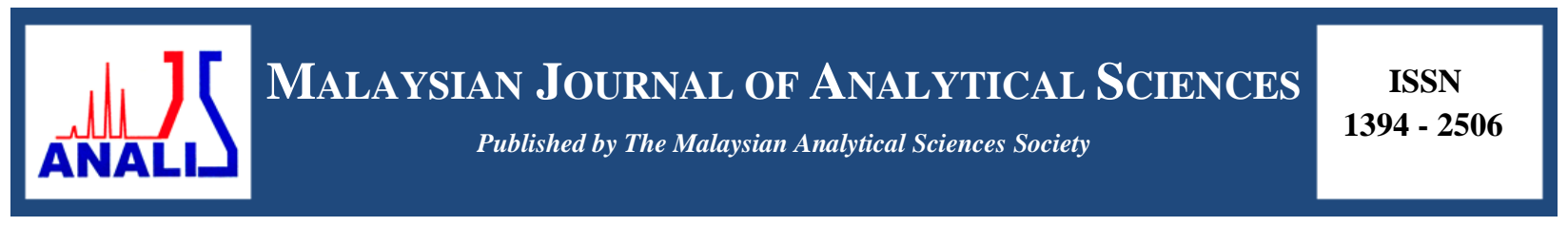

\title{
SYNTHESIS AND CHARACTERIZATION OF BENZOHYDROXAMIC ACID AND METHYLBENZOHYDROXAMIC ACID METAL COMPLEXES AND THEIR CYTOTOXICTY STUDY
}

\author{
(Sintesis dan Pencirian Kompleks Logam Asid Benzohidroksamik dan Asid \\ Metilbenzohidroksamik serta Kajian Sitotoksik)
}

\author{
Latifah Robbaniyyah Hassan ${ }^{1}$, Hadariah Bahron ${ }^{1}$, Kalavathy Ramasamy ${ }^{3}$, Amalina Mohd Tajuddin ${ }^{1,2} *$ \\ ${ }^{I}$ Faculty of Applied Sciences, \\ Universiti Teknologi MARA, 40450 Shah Alam, Selangor, Malaysia \\ ${ }^{2}$ Atta-ur-Rahman Institute for Natural Product Discovery \\ ${ }^{3}$ Faculty of Pharmacy \\ Universiti Teknologi MARA, 42300 Bandar Puncak Alam, Selangor, Malaysia \\ *Corresponding author: amalina9487@salam.uitm.edu.my
}

Received: 29 August 2017; Accepted: 14 March 2019

\begin{abstract}
Hydroxamic acids, RCONHOH, are electronically flexible compounds for organic and inorganic analyses due to their more delicate structures compared to carboxylic acid. These acids are easy to deprotonate to produce hydroxamate ions. The syntheses, physico-chemical and characterization of benzohydroxamic acid (BHA) and methylbenzohydroxamic acid $\left(\mathrm{CH}_{3}-\mathrm{BHA}\right)$ and their metal complexes $\mathrm{VO}(\mathrm{IV}), \mathrm{Cr}(\mathrm{III})$ and $\mathrm{Ni}(\mathrm{II})$ are reported herein. The metal complexes were synthesized by condensation reaction of BHA and $\mathrm{CH}_{3}$-BHA with metal salts in 2:1 molar ratio. The compounds were characterized by elemental analysis, infrared spectroscopy (IR), ${ }^{1} \mathrm{H}$ and ${ }^{13} \mathrm{C}$ NMR, UV-Vis, TGA, magnetic susceptibility and molar conductance. From IR and magnetic susceptibility data, each complex is coordinated to the metal via oxygen and oxygen $(O, O)$ in bidentate manner. The geometry of all metal complexes is octahedral except for $\left[\mathrm{VO}(\mathrm{BHA})_{2}\right]$ that is square-pyramidal. The molar conductance values suggested that all complexes are non-electrolytic. A cytotoxicity study against human colorectal cancer, HCT116 cell lines, revealed that all the complexes are better anticancer agents than their parent ligands.
\end{abstract}

Keywords: hydroxamic acid, vanadium(IV), chromium(III), nickel(II), cytotoxicity

\section{Abstrak}

Asid hidroksamik, RCONHOH, adalah sebatian yang anjal elektronik untuk analisis organik and bukan organik kerana strukturnya yang lebih rapuh jika dibandingkan dengan asid karboksilat. Asid ini mudah untuk deprotonasi untuk menghasilkan ion hidrosamat. Sintesis, fizikokimia dan pencirian asid benzohidroksamik $(\mathrm{BHA})$ dan asid metilbenzohidroksamik $\left(\mathrm{CH}_{3}-\mathrm{BHA}\right)$ dan logam kompleksnya $\mathrm{VO}(\mathrm{IV}), \mathrm{Cr}(\mathrm{III})$ dan $\mathrm{Ni}(\mathrm{II})$ telah dilaporkan disini. Logam kompleks telah disintesis melalui kondensasi antara BHA dan $\mathrm{CH}_{3}$-BHA dengan garam logam dalam nisbah molar 2:1. Semua sebatian yang dihasilkan telah dicirikan menggunakan analisis asas, spektroskopi inframerah (IR), ${ }^{1} \mathrm{H}$ dan ${ }^{13} \mathrm{C} \mathrm{NMR}$, UV-Vis, TGA, kerentanan magnet dan kekonduksian molar. Setiap kompleks logam berkoordinasi dengan logam melalui atom oksigen dan oksigen $(O, O)$ dengan cara bidentat daripada data IR dan kerentanan magnet. Geometri untuk semua kompleks adalah geometri beroktahedron kecuali $\left[\mathrm{VO}(\mathrm{BHA})_{2}\right]$ yang geometrinya adalah piramid segi empat sama. Semua kompleks logam adalah bukan elektrolit berdasarkan nilai kekonduksian molar. Kajian sitotoksik terhadap HCT116 menunjukkan bahawa semua kompleks logam adalah agen antikanser yang lebih baik daripada ligan induk mereka.

Kata kunci: asid hidroksamik, vanadium(IV), kromium(III), nikel(II), sitotoksik 


\section{Latifah Robbaniyyah et al: SYNTHESIS AND CHARACTERIZATION OF BENZOHYDROXAMIC ACID AND METHYLBENZOHYDROXAMIC ACID METAL COMPLEXES AND THEIR CYTOTOXICTY STUDY}

\section{Introduction}

Hydroxamic acids have a potent functional group, $-\mathrm{CONHOH}$, that plays an important role in forming therapeutic agents [1]. The ease of deprotonation of the $\mathrm{CONHOH}$ moiety to produce hydroxamate ion makes this acid more electronically flexible than its analogous carboxylic acid. As such, hydroxamic acids have received a lot of attention due to their importance in fulfilling a variety of roles in biology and medicine [2] such as being anticancer agents, inhibitors for sperm mobility and antiamoebic agents [3]. Ability to form stable metal chelates and possible NOreleasing properties also lead to their versatility in biological activity $[2,4]$.

Vanadium, chromium and nickel complexes of BHA have been tested for their bioactivity and reported to possess anticancer properties; and its vanadium and chromium complexes have additional potential applications in treating diabetes [5]. However, studies on the effect of substituent groups in hydroxamic acid complexes on cytotoxicity are scarce. Thus, the anticancer properties of BHA as well as their methyl substituted counterparts' ligands and their metal complexes were investigated. This paper reports the synthesis, characterization and anticancer screening against $\mathrm{HCT} 116$ of BHA and $\mathrm{CH}_{3}$-BHA as well as those of their $\mathrm{VO}(\mathrm{IV}), \mathrm{Cr}(\mathrm{III}), \mathrm{Ni}(\mathrm{II})$ complexes.

\section{Materials and Methods}

All chemicals and reagents were purchased from Sigma Aldrich and Merck and used without prior purification. Benzohydroxamic acid was purchased from Merck. The percentage composition of the elements $\mathrm{C}, \mathrm{H}$ and $\mathrm{N}$ of the compounds were determined by using Thermo Scientific Flash 2000 Elemental Analyzer with methionine as a standard. Melting points were determined in capillaries using Stuart SMP10 and were uncorrected. The infrared spectra (IR) were recorded using a Perkin-Elmer Model 1750X FTIR spectrophotometer in the range of $4000 \square 400$ $\mathrm{cm}^{-1}$ as $\mathrm{KBr}$ discs. The ${ }^{1} \mathrm{H}$ and ${ }^{13} \mathrm{C}$ NMR spectra were recorded on a Bruker Varian-600MHz using TMS as an internal standard in DMSO. The UV-Vis spectra were obtained in absolute ethanol in the 200-900 nm range using Perkin Elmer UV-Vis Lambda 35 spectrophotometer at room temperature. The thermal decomposition behavior of the metal complexes was recorded using NETZSCH TG 209 F3 under nitrogen atmosphere at heating rate of $10{ }^{\circ} \mathrm{C} \mathrm{min}{ }^{-1}$ from room temperature to $900{ }^{\circ} \mathrm{C}$. Magnetic moments for the prepared complexes were characterized using the Guoy method with water as calibrant on Sherwood Auto Magnetic Susceptibility Balance. Molar conductivity measurements of BHA and $\mathrm{CH}_{3}$-BHA series were determined in dimethylsulfoxide, DMSO and absolute ethanol $\left(\sim 10^{-3} \mathrm{M}\right)$ at room temperature using a Mettler Toledo Inlab 730 conductivity meter.

\section{Synthesis of methylbenzohydroxamic acid}

The synthesis of $\mathrm{CH}_{3}$-BHA is presented in Scheme 1.

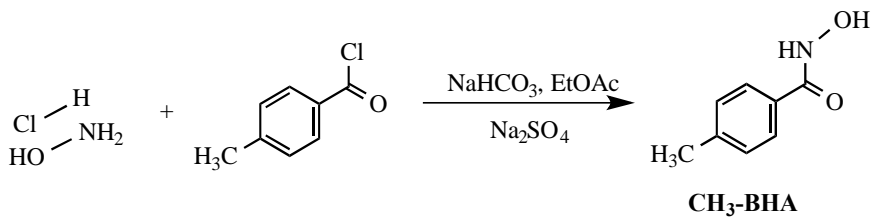

Scheme 1. Overall reaction of $\mathrm{CH}_{3}-\mathrm{BHA}$

Hydroxylamine hydrochloride ( $12 \mathrm{mmol}, 0.9555 \mathrm{~g}$ ) was added to a mixture solution of ethyl acetate and water containing sodium hydrogen carbonate $\left(\mathrm{NaHCO}_{3}\right)$. The mixture was stirred at room temperature. 4-methylbenzoyl chloride $(10 \mathrm{mmol}, 1.5640 \mathrm{~g})$ was diluted with small amounts of ethyl acetate added dropwise to the mixture. The mixture was stirred for 5 minutes at room temperature. The organic layer was separated from aqueous layer, dried with anhydrous sodium sulphate. The solvent was removed in vacuo to afford pure product. Yield: $100 \%$. 


\section{Synthesis of metal complexes}

The reaction of metal salts with BHA and its derivative, $\mathrm{CH}_{3}$ - $\mathrm{BHA}$ in 1:2 molar ratio is presented in Scheme 2 .

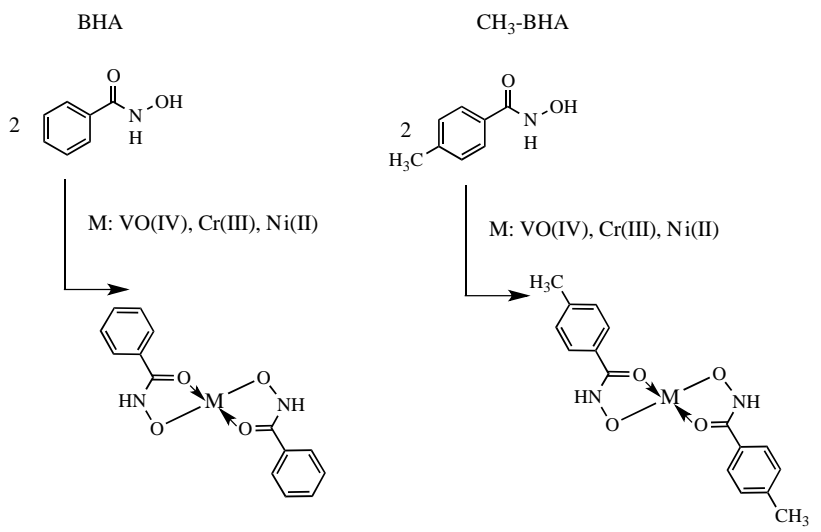

Scheme 2. General complexation reaction of $\mathrm{BHA}$ and $\mathrm{CH}_{3}$-BHA

\section{Synthesis of vanadyl benzohydroxamic acid [ $\left.\mathrm{VO}(\mathrm{BHA})_{2}\right]$}

BHA (10 mmol, $1.5314 \mathrm{~g})$ was dissolved in deionized water and nitrogen gas $\left(\mathrm{N}_{2}\right)$ was bubbled through the solution for 10 minutes. Aqueous solution of vanadium(IV) oxide sulfate hydrate, $\mathrm{VOSO}_{4} \cdot \mathrm{xH}_{2} \mathrm{O}(5 \mathrm{mmol}, 0.815 \mathrm{~g})$ was added dropwise. The mixture was stirred for 30 minutes under $\mathrm{N}_{2}$ at room temperature. A black-purplish precipitate was formed. The resulting precipitate was collected by filtration (pore size, $20 \mu \mathrm{m}$ ) and carefully washed with deionized water. The solid obtained was dried in vacuum at room temperature for 24 hours and then stored in a desiccator. Yield: $22.51 \%$.

\section{Synthesis of chromium benzohydroxamic acid $\left[\mathrm{Cr}(\mathrm{BHA})_{2}\left(\mathrm{H}_{2} \mathrm{O}\right)_{2}\right] \cdot \mathrm{H}_{2} \mathrm{O}$}

Chromium(III) chloride hexahydrate, $\mathrm{CrCl}_{2} \cdot 6 \mathrm{H}_{2} \mathrm{O}(1.63 \mathrm{mmol}, 0.4343 \mathrm{~g})$ was dissolved in a hot ethanolic solution $(10 \mathrm{~mL})$ of BHA $(3.26 \mathrm{mmol}, 0.4471 \mathrm{~g})$. The $\mathrm{pH}$ of the resulting solution was adjusted to 5.5 using $0.1 \mathrm{M} \mathrm{NaOH}$ solution, where upon a greyish precipitate appeared. The solid obtained was filtered (pore size, $20 \mu \mathrm{m}$ ), washed with distilled water and dried over $\mathrm{P}_{2} \mathrm{O}_{5}$ in vacuum after being left standing at room temperature for 3 hours. Yield: $27.54 \%$.

\section{Synthesis of nickel benzohydroxamic acid [ $\left.\mathrm{Ni}(\mathrm{BHA})_{2}\left(\mathrm{H}_{2} \mathrm{O}\right)(\mathrm{OAc})\right]$}

Nickel(II) acetate tetrahydrate, $\mathrm{Ni}(\mathrm{OAc})_{2} \cdot 4 \mathrm{H}_{2} \mathrm{O}(5 \mathrm{mmol}, 1.2443 \mathrm{~g})$ was added to $10 \mathrm{~mL}$ of hot aqueous solution of BHA ( $5 \mathrm{mmol}, 0.8941 \mathrm{~g}$ ). $0.1 \mathrm{M} \mathrm{NaOH}$ solution was used to adjust the $\mathrm{pH}$ of the resulting solution to 5.5 until a light green precipitate appeared. The precipitate was collected through filtration (pore size, $20 \mu \mathrm{m}$ ) and washed with distilled water. The light green precipitate was left standing at room temperature before being dried over $\mathrm{P}_{2} \mathrm{O}_{5}$ in vacuum. Yield: $48.26 \%$.

\section{Synthesis of vanadium methylbenzohydroxamic acid $\left[\mathrm{VO}\left(\mathrm{CH}_{3}-\mathrm{BHA}\right)_{2}\right] \cdot \mathrm{H}_{2} \mathrm{O}$}

The solution of $\mathrm{CH}_{3}$-BHA ( $5 \mathrm{mmol}, 0.7657 \mathrm{~g}$ ) in deionized water was bubbled with $\mathrm{N}_{2}$ for 10 minutes before being added dropwise with an aqueous solution of $\mathrm{VOSO}_{4} \cdot \mathrm{xH}_{2} \mathrm{O}(2.5 \mathrm{mmol}, 0.4075 \mathrm{~g})$. The mixture was stirred under $\mathrm{N}_{2}$ at room temperature for 30 minutes until a black-purplish precipitate appeared. The precipitate was collected by filtration (pore size, $20 \mu \mathrm{m}$ ) and washed with deionized water. The precipitate obtained was dried in vacuum at room temperature for 24 hours before being stored in a desiccator. Yield: $34.96 \%$.

\section{Synthesis of chromium methylbenzohydroxamic acid $\left[\mathrm{Cr}\left(\mathrm{CH}_{3}-\mathrm{BHA}\right)_{2}\left(\mathrm{H}_{2} \mathrm{O}\right)_{2}\right] .2 \mathrm{H}_{2} \mathrm{O}$}

$10 \mathrm{~mL}$ of hot ethanolic solution was used to dissolve $\mathrm{CH}_{3}$ - $\mathrm{BHA}(10 \mathrm{mmol}, 1.4356 \mathrm{~g}) . \mathrm{CrCl}_{3} \cdot 6 \mathrm{H}_{2} \mathrm{O}(5 \mathrm{mmol}, 0.6661$ g) was dissolved in a hot ultra-pure water $(5 \mathrm{~mL})$ and was mixed with the $\mathrm{CH}_{3}$-BHA ethanolic solution. The greyish precipitate obtained was filtered off (pore size, $20 \mu \mathrm{m}$ ), washed with cold ethanol and dried over $\mathrm{P}_{2} \mathrm{O}_{5}$ in vacuum after being left standing at room temperature for 6 hours. Yield: $44.13 \%$. 


\section{Latifah Robbaniyyah et al: SYNTHESIS AND CHARACTERIZATION OF BENZOHYDROXAMIC ACID AND METHYLBENZOHYDROXAMIC ACID METAL COMPLEXES AND THEIR CYTOTOXICTY STUDY}

\section{Synthesis of nickel methylbenzohydroxamic acid $\left[\mathrm{Ni}\left(\mathrm{CH}_{3}-\mathrm{BHA}\right)_{2}\left(\mathrm{H}_{2} \mathrm{O}\right)_{2}\right] .2 \mathrm{H}_{2} \mathrm{O}$}

$\mathrm{CH}_{3}$-BHA (10 mmol, $1.657 \mathrm{~g}$ ) was dissolved in hot ethanol $(10 \mathrm{~mL}) .5 \mathrm{~mL}$ of hot ultra-pure water was added to $\mathrm{Ni}(\mathrm{OAc})_{2} \cdot 4 \mathrm{H}_{2} \mathrm{O}(5 \mathrm{mmol}, 1.2443 \mathrm{~g})$ before mixing with the ethanolic solution of $\mathrm{CH}_{3}-\mathrm{BHA}$. The mixture produced a light green precipitate. The precipitate was collected using filtration (pore size, $20 \mu \mathrm{m}$ ) and washed with cold ethanol before storing in desiccator. Yield: 7.96\%.

\section{Cytotoxicity study: Cell culture}

The human colorectal carcinoma cell line, HCT116 (ATCC® CCL-247TM), was cultured in the Roswell Park Memorial Institute RPMI 1640 Medium w/ 25mM HEPES \& L-Glutamine, Biowest, supplemented with $10 \%$ heat inactivated fetal bovine serum (FBS) (PAA Laboratories) and $1 \%$ penicillin/streptomycin, Sigma Aldrich, (St Louis, US). Cultures were maintained in a humidified incubator at $37^{\circ} \mathrm{C}$ in an atmosphere of $5 \% \mathrm{CO}_{2}$.

\section{MTT assay}

HCT116 cells were plated at 7,000 cells per well and allowed to incubate at $37^{\circ} \mathrm{C}$ for 24 hours. BHA and $\mathrm{CH}_{3}$-BHA ligand and their metal complexes were subjected to serial dilutions before being added to each well. The cells were treated with the compounds at concentrations ranging between $0.01-100 \mu \mathrm{M}$ and incubated at $37{ }^{\circ} \mathrm{C}$ for 72 hours. The cytotoxicity of the compounds was assessed using the MTT method utilizing 3-(4,5-dimethylthiazol2-yl)-2,5-diphenyl tetrazolium bromide (MTT or formazan) with minor modifications [6]. Briefly, $50 \mu \mathrm{L}$ of 0.06 $\mathrm{mol} / \mathrm{L}$ MTT solution was added to each well and plates were incubated at $37{ }^{\circ} \mathrm{C}$ for 4 hours. All solutions were removed and DMSO was added to dissolve the formazan crystals. The plates were read at $450 \mathrm{~nm}$. Data generated were used to plot a dose-response curve from which the concentration of compounds required to kill $50 \%$ of cell population $\left(\mathrm{IC}_{50}\right)$ was determined.

\section{Physical properties and elemental analysis}

\section{Results and Discussion}

The physical characteristics and elemental analysis results of all compounds are shown in Table 1. BHA, $\mathrm{CH}_{3}-\mathrm{BHA}$ and their $\mathrm{VO}(\mathrm{IV}), \mathrm{Cr}(\mathrm{III})$ and $\mathrm{Ni}$ (II) complexes are air-stable and relatively well soluble in polar organic solvents such as DMSO and DMF. The stoichiometry of all compounds was confirmed by elemental analysis $(\mathrm{C}, \mathrm{H}, \mathrm{N})$. Bisbidentate complexes were obtained upon reaction between the ligands, $\mathrm{BHA}$ and $\mathrm{CH}_{3}-\mathrm{BHA}$, with metal ions at 2:1 molar ratio. The analytical data are in good agreement with the calculated stoichiometry of the compounds.

Table 1. Physical data of BHA and $\mathrm{CH}_{3}-\mathrm{BHA}$ and their metal complexes

\begin{tabular}{|c|c|c|c|c|c|c|c|}
\hline \multirow[t]{2}{*}{ Ligand/ Complex } & \multirow[t]{2}{*}{$\begin{array}{l}\text { Molecular } \\
\text { Formula }\end{array}$} & \multirow{2}{*}{$\begin{array}{c}\text { Molecular } \\
\text { Weight } \\
\text { (g/mol) }\end{array}$} & \multirow[t]{2}{*}{ Colour } & \multirow{2}{*}{$\begin{array}{c}\text { Melting } \\
\text { Point } \\
\left({ }^{\circ} \mathbf{C}\right)\end{array}$} & \multicolumn{3}{|c|}{$\begin{array}{c}\text { Found } \\
\text { (Calculated)\% }\end{array}$} \\
\hline & & & & & $\mathbf{C}$ & $\mathbf{H}$ & $\mathbf{N}$ \\
\hline$\left[\mathrm{VO}(\mathrm{BHA})_{2}\right]$ & $\mathrm{C}_{14} \mathrm{H}_{12} \mathrm{~N}_{2} \mathrm{O}_{5} \mathrm{~V}$ & 339.20 & $\begin{array}{l}\text { Black- } \\
\text { purplish }\end{array}$ & $140-142$ & $\begin{array}{c}49.57 \\
(49.77)\end{array}$ & $\begin{array}{c}3.57 \\
(3.65)\end{array}$ & $\begin{array}{c}8.26 \\
(9.47)\end{array}$ \\
\hline$\left[\mathrm{Cr}(\mathrm{BHA})_{2}\left(\mathrm{H}_{2} \mathrm{O}\right)_{2}\right] \cdot \mathrm{H}_{2} \mathrm{O}$ & $\mathrm{C}_{14} \mathrm{H}_{18} \mathrm{~N}_{2} \mathrm{O}_{7} \mathrm{Cr}$ & 378.30 & $\begin{array}{l}\text { Muddy } \\
\text { green }\end{array}$ & $\begin{array}{l}\text { Decomposed } \\
\text { at } 280\end{array}$ & $\begin{array}{c}44.45 \\
(44.27)\end{array}$ & $\begin{array}{c}4.80 \\
(4.10)\end{array}$ & $\begin{array}{c}7.41 \\
(7.96)\end{array}$ \\
\hline$\left[\mathrm{Ni}(\mathrm{BHA})_{2}\left(\mathrm{H}_{2} \mathrm{O}\right)(\mathrm{OAc})\right]$ & $\mathrm{C}_{14} \mathrm{H}_{12} \mathrm{~N}_{2} \mathrm{O}_{4} \mathrm{Ni}$ & 330.95 & $\begin{array}{l}\text { Light } \\
\text { green }\end{array}$ & $\begin{array}{l}\text { Decomposed } \\
\text { at } 240\end{array}$ & $\begin{array}{c}50.81 \\
(49.56)\end{array}$ & $\begin{array}{c}3.65 \\
(3.75)\end{array}$ & $\begin{array}{c}8.46 \\
(8.35)\end{array}$ \\
\hline $\mathrm{CH}_{3}$-BHA & $\mathrm{C}_{8} \mathrm{H}_{9} \mathrm{NO}_{2}$ & 151.20 & Peach & $152-154$ & $\begin{array}{l}62.64 \\
(63.56)\end{array}$ & $\begin{array}{c}5.86 \\
(6.00)\end{array}$ & $\begin{array}{c}9.72 \\
(9.27)\end{array}$ \\
\hline$\left[\mathrm{VO}\left(\mathrm{CH}_{3}-\mathrm{BHA}\right)_{2}\right] \cdot \mathrm{H}_{2} \mathrm{O}$ & $\mathrm{C}_{16} \mathrm{H}_{16} \mathrm{~N}_{2} \mathrm{O}_{5} \mathrm{~V}$ & 367.25 & $\begin{array}{l}\text { Black- } \\
\text { purplish }\end{array}$ & $153-156$ & $\begin{array}{c}50.12 \\
(49.88)\end{array}$ & $\begin{array}{c}4.44 \\
(4.71)\end{array}$ & $\begin{array}{c}7.37 \\
(7.27)\end{array}$ \\
\hline
\end{tabular}


Table 2 (cont'd). Physical data of BHA and $\mathrm{CH}_{3}$-BHA and their metal complexes

\begin{tabular}{|c|c|c|c|c|c|c|c|}
\hline \multirow[t]{2}{*}{ Ligand/ Complex } & \multirow[t]{2}{*}{$\begin{array}{l}\text { Molecular } \\
\text { Formula }\end{array}$} & \multirow{2}{*}{$\begin{array}{c}\text { Molecular } \\
\text { Weight } \\
\text { (g/mol) }\end{array}$} & \multirow[t]{2}{*}{ Colour } & \multirow{2}{*}{$\begin{array}{c}\text { Melting } \\
\text { Point } \\
\left({ }^{\circ} \mathrm{C}\right)\end{array}$} & \multicolumn{3}{|c|}{$\begin{array}{c}\text { Found } \\
\text { (Calculated)\% }\end{array}$} \\
\hline & & & & & $\mathbf{C}$ & $\mathbf{H}$ & $\mathbf{N}$ \\
\hline$\left[\mathrm{Cr}\left(\mathrm{CH}_{3}-\mathrm{BHA}\right)_{2}\left(\mathrm{H}_{2} \mathrm{O}\right)_{2}\right] .2 \mathrm{H}_{2} \mathrm{O}$ & $\mathrm{C}_{16} \mathrm{H}_{16} \mathrm{~N}_{2} \mathrm{O}_{4} \mathrm{Cr}$ & 352.31 & Grey & $\begin{array}{l}\text { Decomposed } \\
\text { at } 250\end{array}$ & $\begin{array}{c}45.52 \\
(45.29)\end{array}$ & $\begin{array}{c}5.31 \\
(5.70)\end{array}$ & $\begin{array}{c}6.23 \\
(6.60)\end{array}$ \\
\hline$\left[\mathrm{Ni}\left(\mathrm{CH}_{3}-\mathrm{BHA}\right)_{2}\left(\mathrm{H}_{2} \mathrm{O}\right)_{2}\right] \cdot 2 \mathrm{H}_{2} \mathrm{O}$ & $\mathrm{C}_{16} \mathrm{H}_{16} \mathrm{~N}_{2} \mathrm{O}_{4} \mathrm{Ni}$ & 359.01 & $\begin{array}{l}\text { Light } \\
\text { green }\end{array}$ & $\begin{array}{c}\text { Decomposed } \\
\text { at } 250\end{array}$ & $\begin{array}{c}44.68 \\
(44.58)\end{array}$ & $\begin{array}{c}5.23 \\
(5.61)\end{array}$ & $\begin{array}{c}6.50 \\
(6.12)\end{array}$ \\
\hline
\end{tabular}

\section{Infrared spectroscopy}

The coordination modes of ligands towards the metal ions can be determined from IR spectral studies. IR provides invaluable information on bonding and functional groups that exist in the compounds. The mode of coordination can be inferred through the shifting, disappearance and appearance of the new bands on the spectra of BHA, $\mathrm{CH}_{3}$-BHA in their $\mathrm{VO}$ (IV), $\mathrm{Cr}$ (III) and $\mathrm{Ni}(\mathrm{II})$ complexes. The main infrared bands and their assignments are listed in Table 3. The IR spectra of BHA and $\mathrm{CH}_{3}$-BHA with their metal complexes are shown in Figure 1 and Figure 2, respectively.

Table 3. Infrared spectral data for BHA and $\mathrm{CH}_{3} \square \mathrm{BHA}$ series complexes

\begin{tabular}{lcccccc}
\hline \multirow{2}{*}{ Ligands/Complexes } & \multicolumn{7}{c}{ Frequency $\left(\mathbf{c m}^{-\mathbf{1}}\right)$} \\
\cline { 2 - 7 } & $\mathbf{N - H}$ & $\mathbf{O H}$ & $\mathbf{C = O}$ & $\mathbf{N}-\mathbf{O}$ & $\mathbf{V = O}$ & $\mathbf{M - O}$ \\
\hline $\mathrm{BHA}$ & $3297(s)$ & $2749(b r)$ & $1647(s)$ & $899(s)$ & - & - \\
{$\left[\mathrm{VO}(\mathrm{BHA})_{2}\right]$} & - & - & $1605(s)$ & $926(s)$ & $994(s)$ & $484(w)$ \\
{$\left[\mathrm{Cr}(\mathrm{BHA})_{2}\left(\mathrm{H}_{2} \mathrm{O}\right)_{2}\right] \cdot \mathrm{H}_{2} \mathrm{O}$} & - & - & $1602(s)$ & $917(s)$ & - & $489(w)$ \\
{$\left[\mathrm{Ni}(\mathrm{BHA})_{2}\left(\mathrm{H}_{2} \mathrm{O}\right)(\mathrm{OAc})\right]$} & $3226(s)$ & - & $1601(s)$ & $915(s)$ & - & $487(w)$ \\
$\mathrm{CH}_{3}-\mathrm{BHA}$ & $3294(s)$ & $2759(b r)$ & $1651(s)$ & $903(s)$ & - & - \\
{$\left[\mathrm{VO}\left(\mathrm{CH}_{3}-\mathrm{BHA}\right)_{2}\left(\mathrm{H}_{2} \mathrm{O}\right)_{2}\right] \cdot 2 \mathrm{H}_{2} \mathrm{O}$} & - & - & $1649(s h)$ & $917(s)$ & $968(s)$ & $487(w)$ \\
{$\left[\mathrm{Cr}\left(\mathrm{CH}_{3}-\mathrm{BHA}\right)_{2}\left(\mathrm{H}_{2} \mathrm{O}\right)_{2}\right] \cdot 2 \mathrm{H}_{2} \mathrm{O}$} & $3216(b)$ & - & $1648(s h)$ & $917(m)$ & - & $478(w)$ \\
{$\left[\mathrm{Ni}\left(\mathrm{CH}_{3}-\mathrm{BHA}\right)_{2}\left(\mathrm{H}_{2} \mathrm{O}\right)_{2}\right] \cdot 2 \mathrm{H}_{2} \mathrm{O}$} & $3232(m)$ & - & $1605(s)$ & $917(s)$ & - & $458(w)$ \\
\hline
\end{tabular}

Note: $s=$ strong, $m=$ medium, $w=$ weak, $b=$ broad, $s h=$ shoulder

The spectral investigation of $\mathrm{BHA}, \mathrm{CH}_{3}$ - $\mathrm{BHA}$ spectra with their metal complexes indicated that the complexation had indeed occurred, in a bis-bidentate manner through the oxygen of the carbonyl $(\mathrm{C}=\mathrm{O})$ and hydroxyl $(-\mathrm{OH})$ groups. Hence, the coordination mode suggested is the $O, O$ mode. The $\mathrm{N}-\mathrm{H}$ stretching vibrations were observed as strong bands at 3297 and $3294 \mathrm{~cm}^{-1}$ for BHA and $\mathrm{CH}_{3}$-BHA, respectively. In their metal complexes, the $\mathrm{N}-\mathrm{H}$ bands were absent for $\left[\mathrm{VO}(\mathrm{BHA})_{2}\right],\left[\mathrm{Cr}(\mathrm{BHA})_{2}\left(\mathrm{H}_{2} \mathrm{O}\right)_{2}\right] \cdot \mathrm{H}_{2} \mathrm{O}$ and $\left[\mathrm{VO}\left(\mathrm{CH}_{3}-\mathrm{BHA}\right)_{2}\right]$ and shifted to lower wavenumbers for [Ni(BHA $\left.)_{2}\right],\left[\mathrm{Cr}\left(\mathrm{CH}_{3}-\mathrm{BHA}\right)_{2}\right]$ and $\left[\mathrm{Ni}\left(\mathrm{CH}_{3}-\mathrm{BHA}\right)_{2}\right]$. The sharp bands ascribed to $\mathrm{v}(\mathrm{N}-\mathrm{O})$ at 899 and $903 \mathrm{~cm}^{-1}$ of BHA and $\mathrm{CH}_{3}-\mathrm{BHA}$, respectively, were shifted to higher wavenumbers and appeared at $915-926 \mathrm{~cm}^{-1}$ for the complexes, in concordance with the literature values [7].

The O-H bands that appeared in the regions of 2749 and $2759 \mathrm{~cm}^{-1}$ in $\mathrm{BHA}$ and $\mathrm{CH}_{3}-\mathrm{BHA}$ spectra, respectively, are disappeared in all complexes suggesting deprotonation of $\mathrm{OH}$ and coordination of oxygen from the hydroxyl group to the metal ion. The shifting of $v(\mathrm{C}=\mathrm{O})$ towards lower wavenumbers by $42-46 \mathrm{~cm}^{-1}$ in the BHA complexes indicating the involvement of carbonyl $(\mathrm{C}=\mathrm{O})$ group during complexation via oxygen atoms. This is further supported by the appearance of new weak bands of (M-O (M: VO, Cr, Ni) around $458-487 \mathrm{~cm}^{-1}$ in the spectra of complexes of BHA and $\mathrm{CH}_{3}$-BHA, as similarly reported previously [8]. 
However, for $\left[\mathrm{VO}\left(\mathrm{CH}_{3}-\mathrm{BHA}\right)_{2}\right]$ and $\left[\mathrm{Cr}\left(\mathrm{CH}_{3}-\mathrm{BHA}\right)_{2}\right]$, there was no appreciable shifting of $v(\mathrm{C}=\mathrm{O})$ observed in the spectra, but the intensity of the bands was reduced from strong to shoulder bands. This may be explained by the mixing with the $v_{\mathrm{C}=\mathrm{C}}$ aryl moiety. The stretching bands due to $v(\mathrm{C}-\mathrm{N})$ of $\mathrm{BHA}$ and $\mathrm{CH}_{3}-\mathrm{BHA}$ at 1437 and $1441 \mathrm{~cm}^{-1}$, respectively, were observed to have shifted towards higher wavenumbers at 1491 and $1492 \mathrm{~cm}^{-1}$ in the complexes in concordance to Chauhan et al. [9]. [ $\left.\mathrm{VO}(\mathrm{BHA})_{2}\right]$ and $\left[\mathrm{VO}\left(\mathrm{CH}_{3}-\mathrm{BHA}\right)_{2}\right.$ ] displayed new bands at 994 and $968 \mathrm{~cm}^{-1}$, respectively, assignable to the stretches of $\mathrm{V}=\mathrm{O}[10,11]$.

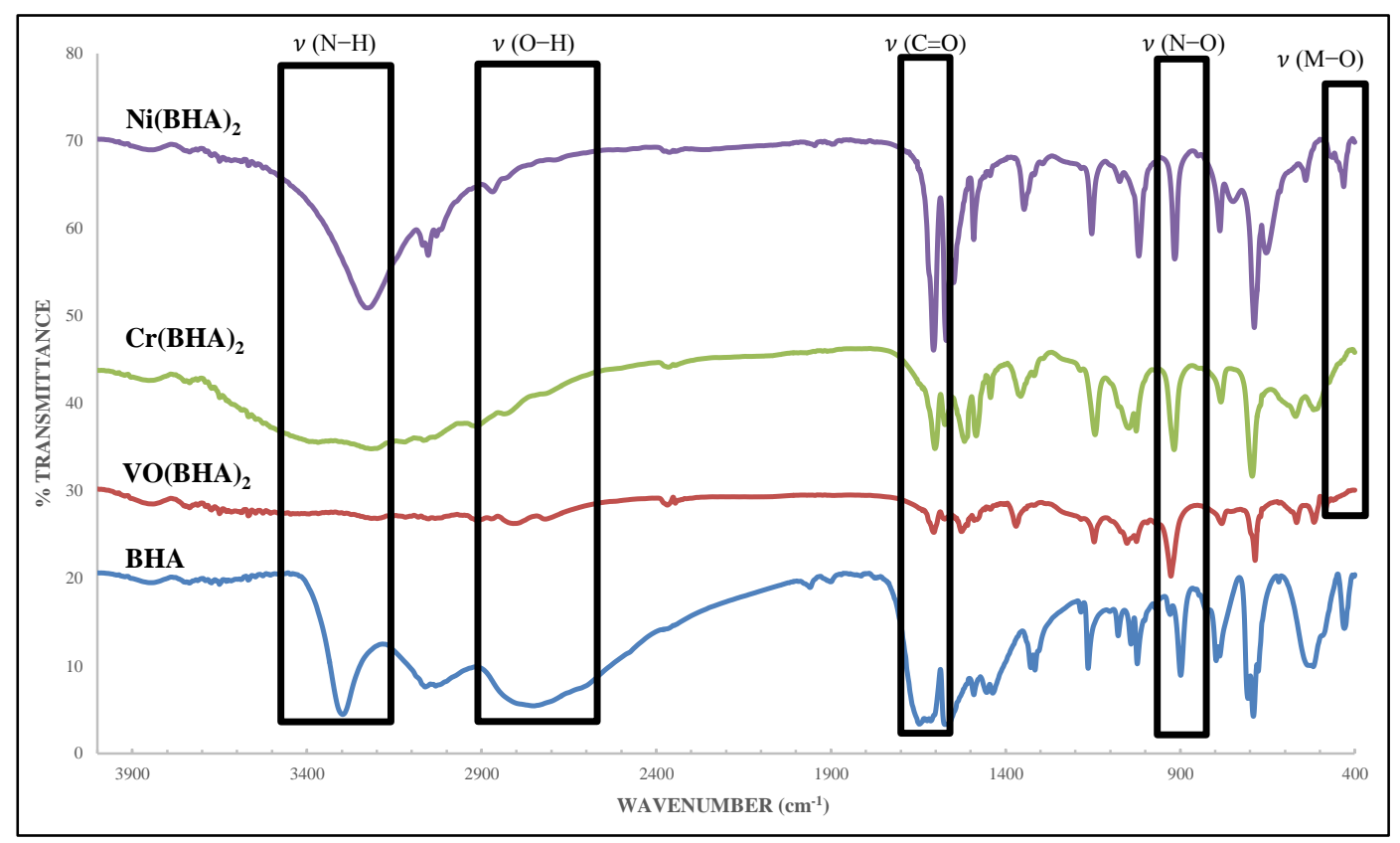

Figure 1. IR spectra for BHA series

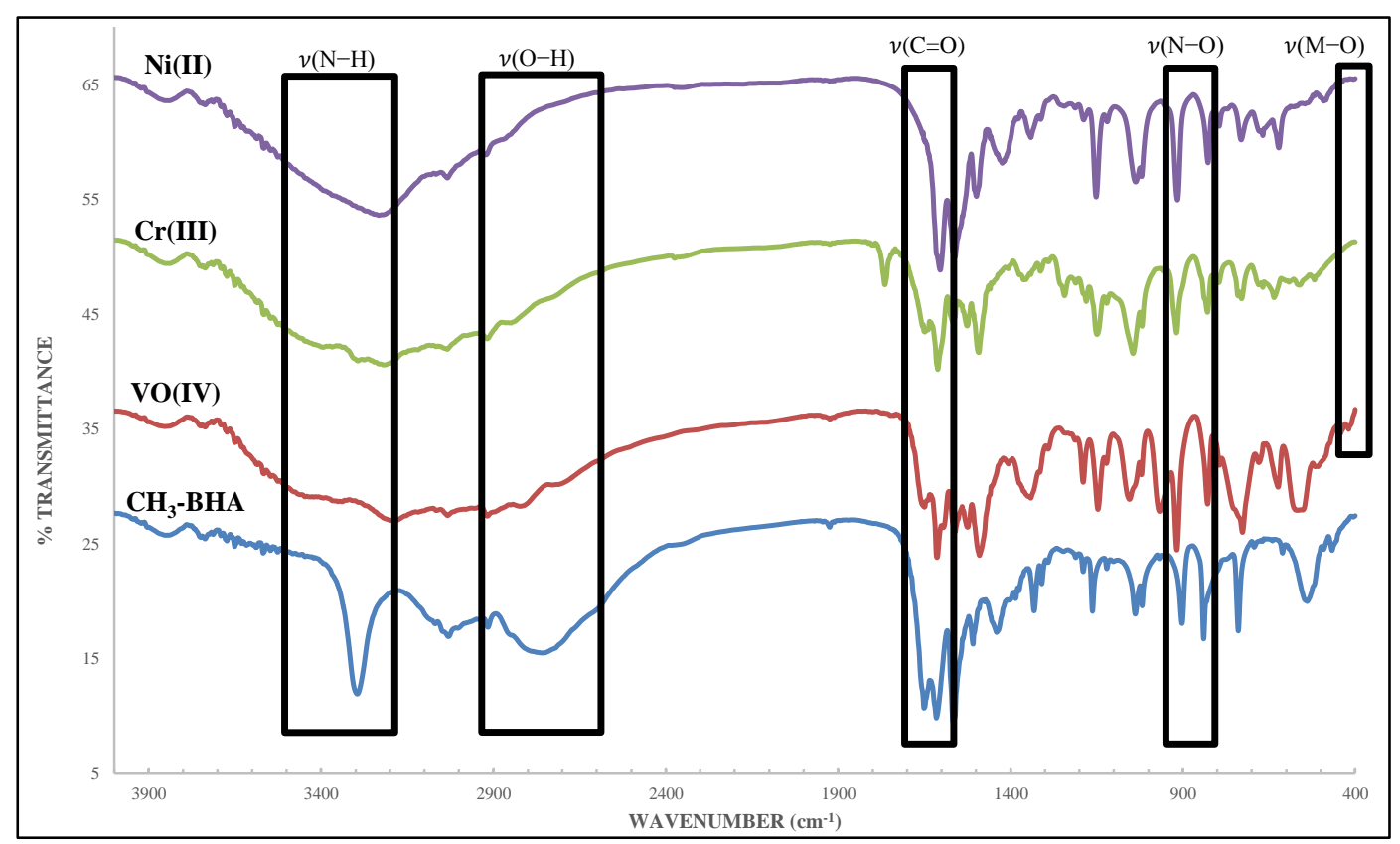

Figure 2. IR spectra for $\mathrm{CH}_{3}$-BHA series 


\section{Nuclear magnetic spectroscopy}

The ${ }^{1} \mathrm{H}$ and ${ }^{13} \mathrm{C}$ NMR spectra for the ligands were recorded in DMSO- $\mathrm{d}_{6}$ using tetramethylsilane (TMS) as the internal standard. BHA shows two downfield singlets at 9.08 and $11.24 \mathrm{ppm}$ due to $\mathrm{NH}$ and $\mathrm{OH}$ protons, respectively [12]. For $\mathrm{CH}_{3}$ - $\mathrm{BHA}, \mathrm{NH}$ and $\mathrm{OH}$ protons were not observed due to the proton exchange with the deuterium that makes the peaks disappeared [13]. The ${ }^{1} \mathrm{H}$ NMR spectrum of BHA exhibits 3 resonances at 7.41$7.48,7.50$ and $7.76 \mathrm{ppm}$ corresponding to the five protons of the benzene ring, while that of $\mathrm{CH}_{3} \square \mathrm{BHA}$ has 2 resonances at 7.23 and $7.62 \mathrm{ppm}$ corresponding to four protons of the para-substituted derivative [12]. The methyl $\left(\mathrm{CH}_{3}\right)$ protons peaks appeared at $2.41 \mathrm{ppm}$.

${ }^{13} \mathrm{C}$ NMR was used on determining the number of nonequivalent carbons and types of carbons that exists in the ligands. Both information from ${ }^{1} \mathrm{H}$ NMR and IR are helping on determining the structure of the ligands together with ${ }^{13} \mathrm{C}$ NMR. There are 3 types of carbons exists in BHA and $\mathrm{CH}_{3}-\mathrm{BHA}$. They are carbonyl $(\mathrm{C}=\mathrm{O})$, aromatic carbon (Ar-C) and methyl carbon. The carbonyl $(\mathrm{C}=\mathrm{O})$ signals appeared at 164.79 and $164.03 \mathrm{ppm}$, respectively for BHA and $\mathrm{CH}_{3}$-BHA [14]. The aromatic carbon for BHA appeared at $127.32-133.21 \mathrm{ppm}$, while for $\mathrm{CH}_{3}$-BHA, these carbons appeared at $126.73-130.26 \mathrm{ppm}$. The methyl carbon appeared at $20.89 \mathrm{ppm} .{ }^{1} \mathrm{H}$ and ${ }^{13} \mathrm{C}$ NMR for all complexes could not be obtained due to paramagnetic behaviour of all complexes. Paramagnetic means there is an unpaired electron existing in the orbital that is slightly attracted to the magnetic fields thus making all the NMR signals vanished and difficult to assign [15].

\section{Ultraviolet-visible spectroscopy}

The geometry of the complexes can be predicted from UV-Vis study. The UV-Vis spectrum of BHA and $\mathrm{CH}_{3}$-BHA and their $\mathrm{VO}(\mathrm{IV}), \mathrm{Cr}(\mathrm{III})$ and $\mathrm{Ni}(\mathrm{II})$ complexes were carried out as $10^{-3} \times 10^{-4} \mathrm{M}$ in ethanol in the range of $900-200$ $\mathrm{nm}$. UV-Vis analysis of $\left[\mathrm{Ni}\left(\mathrm{CH}_{3}-\mathrm{BHA}\right)_{2}\right]$ cannot be performed due to the solubility problem. The absorption spectrum of BHA and $\mathrm{CH}_{3}$ - $\mathrm{BHA}$ consists of an intense band centered at 220 and $236 \mathrm{~nm}$, respectively attributed to $\pi \rightarrow \pi^{*}$ transitions of aromatic rings. Another weak band observed was related to $\mathrm{n} \rightarrow \pi^{*}$ transitions within $\mathrm{C}=\mathrm{O}$ found at $336 \mathrm{~nm}$ for BHA but for $\mathrm{CH}_{3}$-BHA, this transition was not observed. $\pi \rightarrow \pi^{*}$ transitions were found shifted to the lower regions in BHA and $\mathrm{CH}_{3}$-BHA complexes. No $\mathrm{n} \rightarrow \pi^{*}$ transition was observed in $\mathrm{VO}\left(\mathrm{CH}_{3}-\mathrm{BHA}\right)_{2}$ spectrum. $\mathrm{n} \rightarrow \pi^{*}$ transitions of $\left[\mathrm{Cr}\left(\mathrm{CH}_{3}-\mathrm{BHA}\right)_{2}\right]$ were found at $312 \mathrm{~nm}$. Ligand-to-metal charge transfer (LMCT) bands were observable in the spectrum of [ $\left.\mathrm{VO}(\mathrm{BHA})_{2}\right]$ at $480 \mathrm{~nm}[16]$.

\section{Thermogravimetric analysis}

The presence and the bonding of water molecules in $\left[\mathrm{Cr}(\mathrm{BHA})_{2}\right] \cdot 3 \mathrm{H}_{2} \mathrm{O}$ were detected by using thermogravimetric analysis and the result is presented in Table 4. TGA graph for $\left[\mathrm{Cr}(\mathrm{BHA})_{2}\right] \cdot 3 \mathrm{H}_{2} \mathrm{O}$ is illustrated in Figure 3 .

Table 4. Thermal behavior indicating the loss of $\mathrm{H}_{2} \mathrm{O}$ molecules from $\left[\mathrm{Cr}(\mathrm{BHA})_{2}\right] \cdot 3 \mathrm{H}_{2} \mathrm{O}$

\begin{tabular}{|c|c|c|c|c|}
\hline \multirow{2}{*}{ Compound } & \multirow{2}{*}{ Temperature Range $\left({ }^{\circ} \mathrm{C}\right)$} & \multicolumn{2}{|c|}{ Weight Loss (\%) } & \multirow{2}{*}{ Lost Species } \\
\hline & & Calculated & Found & \\
\hline$\left[\mathrm{Cr}(\mathrm{BHA})_{2}\left(\mathrm{H}_{2} \mathrm{O}\right)_{2}\right] \cdot \mathrm{H}_{2} \mathrm{O}$ & $154.5-250.64$ & 14.27 & 14.00 & $3 \mathrm{H}_{2} \mathrm{O}$ \\
\hline
\end{tabular}

$\left.\mathrm{Cr}(\mathrm{BHA})_{2}\left(\mathrm{H}_{2} \mathrm{O}\right)_{2}\right] \cdot \mathrm{H}_{2} \mathrm{O}$ clearly indicates the loss of three molar equivalent of water molecules at the temperature of $154.5-250.64{ }^{\circ} \mathrm{C}$ supporting the results of elemental analysis. $\left[\mathrm{Cr}(\mathrm{BHA})_{2}\left(\mathrm{H}_{2} \mathrm{O}\right)_{2}\right] \cdot \mathrm{H}_{2} \mathrm{O}$ was in octahedral geometry by the presence of two molar equivalent of water molecules that coordinated to $\mathrm{Cr}(\mathrm{III})$. Another one molar equivalent of water molecule is lattice water that is present in the sphere of the complex [17]. The proposed structure of $\left[\mathrm{Cr}(\mathrm{BHA})_{2}\left(\mathrm{H}_{2} \mathrm{O}\right)_{2}\right] \cdot \mathrm{H}_{2} \mathrm{O}$ was illustrated in Figure 4. 


\section{Latifah Robbaniyyah et al: SYNTHESIS AND CHARACTERIZATION OF BENZOHYDROXAMIC ACID AND METHYLBENZOHYDROXAMIC ACID METAL COMPLEXES AND THEIR CYTOTOXICTY STUDY}

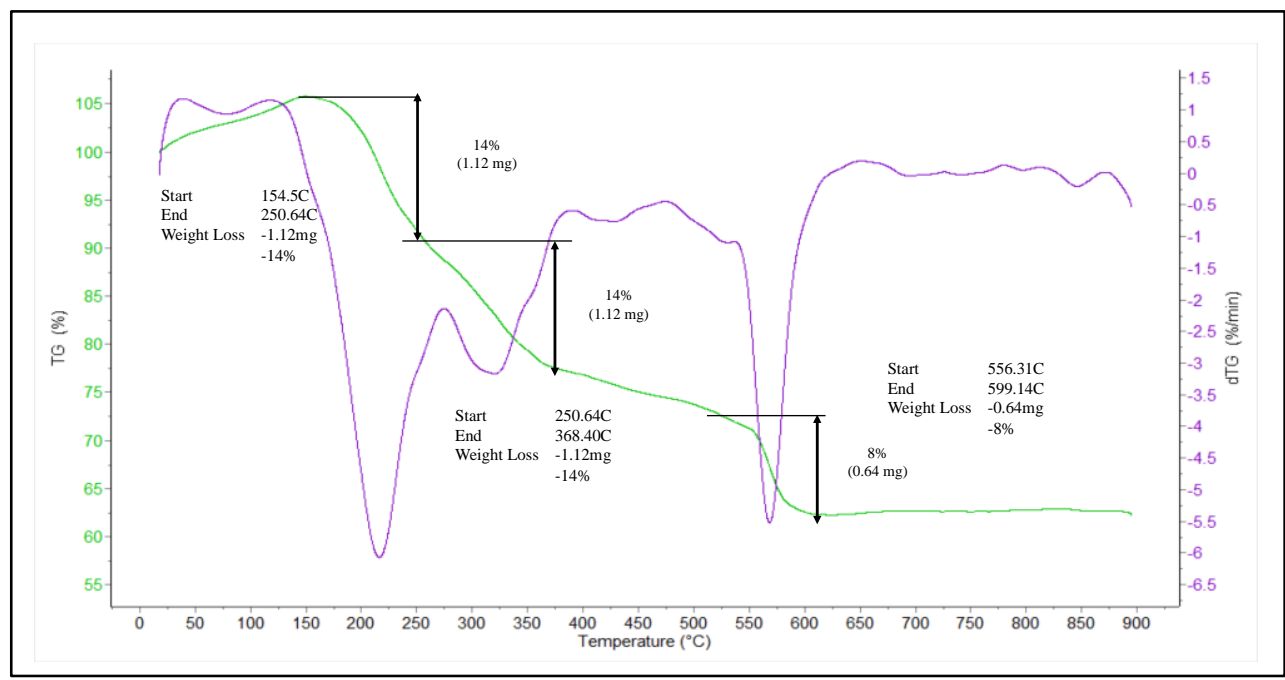

Figure 3. TGA graph of $\left.\mathrm{Cr}(\mathrm{BHA})_{2}\left(\mathrm{H}_{2} \mathrm{O}\right)_{2}\right] \cdot \mathrm{H}_{2} \mathrm{O}$

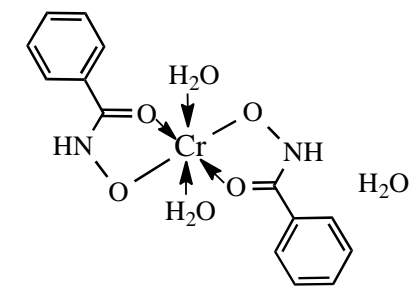

Figure 4. The proposed structure of $\left.\mathrm{Cr}(\mathrm{BHA})_{2}\left(\mathrm{H}_{2} \mathrm{O}\right)_{2}\right] \cdot \mathrm{H}_{2} \mathrm{O}$

\section{Magnetic susceptibility and molar conductivity}

The electrolytic nature and the geometries of all complexes were determined using magnetic susceptibility and molar conductance. Molar conductivities were recorded in $10^{-3} \mathrm{M}$ DMSO at room temperature. Magnetic moments and molar conductivity data for all complexes were tabulated in Table 5.

Table 5. Molar conductance data for $\mathrm{VO}(\mathrm{IV}), \mathrm{Cr}(\mathrm{III})$ and $\mathrm{Ni}(\mathrm{II})$ complexes

\begin{tabular}{lcc}
\hline Complexes & $\boldsymbol{\mu}_{\text {eff }} \mathbf{B . M}$ & $\begin{array}{c}\text { Molar conductance } \\
\left(\boldsymbol{\Omega}^{-1} \mathbf{c m}^{\mathbf{2}} \mathbf{~ m o l}^{-\mathbf{1}}\right)\end{array}$ \\
\hline$\left[\mathrm{VO}(\mathrm{BHA})_{2}\right]$ & 1.57 & 1.00 \\
{$\left[\mathrm{Cr}(\mathrm{BHA})_{2}\left(\mathrm{H}_{2} \mathrm{O}\right)_{2}\right] \cdot \mathrm{H}_{2} \mathrm{O}$} & 3.05 & 3.37 \\
{$\left[\mathrm{Ni}(\mathrm{BHA})_{2}\left(\mathrm{H}_{2} \mathrm{O}\right)(\mathrm{OAc})\right]$} & 3.24 & 6.82 \\
{$\left[\mathrm{VO}\left(\mathrm{CH}_{3}-\mathrm{BHA}\right)_{2}\right] \cdot \mathrm{H}_{2} \mathrm{O}$} & Diamagnetic & 0 \\
{$\left[\mathrm{Cr}\left(\mathrm{CH}_{3}-\mathrm{BHA}\right)_{2}\left(\mathrm{H}_{2} \mathrm{O}\right)_{2}\right] \cdot 2 \mathrm{H}_{2} \mathrm{O}$} & 3.18 & 0 \\
{$\left[\mathrm{Ni}\left(\mathrm{CH}_{3}-\mathrm{BHA}\right)_{2}\left(\mathrm{H}_{2} \mathrm{O}\right)_{2}\right] \cdot 2 \mathrm{H}_{2} \mathrm{O}$} & 2.98 & 0 \\
\hline
\end{tabular}

The proposed magnetic moments for [Ni(BHA $\left.\left.)_{2}\right], \mathrm{Cr}(\mathrm{BHA})_{2}\left(\mathrm{H}_{2} \mathrm{O}\right)_{2}\right] \cdot 2 \mathrm{H}_{2} \mathrm{O},\left[\mathrm{Cr}(\mathrm{BHA})_{2}\left(\mathrm{H}_{2} \mathrm{O}\right)_{2}\right] \cdot \mathrm{H}_{2} \mathrm{O}$, and $\left[\mathrm{Ni}\left(\mathrm{CH}_{3}-\right.\right.$ BHA $\left.)_{2}\right]$ are octahedral geometry $[17,18]$. The magnetic moment for $\left[\mathrm{VO}(\mathrm{BHA})_{2}\right]$ on the range of single electron of 
the $3 d^{1}$ system of square-pyramidal geometry [19]. $\left[\mathrm{VO}\left(\mathrm{CH}_{3}-\mathrm{BHA}\right)_{2}\right]$ has diamagnetic properties. It is suggested that the possible oxidation state of vanadium is $\mathrm{V}^{5+}$. Thus, $\left[\mathrm{VO}\left(\mathrm{CH}_{3}-\mathrm{BHA}\right)_{2}\right]$ may exist in a dimeric nature [20].

Conductivity measurement is usually used on determining structural of metal chelates (mode of coordination) within the limits of their solubility. From Table 5, the molar conductivity $\left(\Lambda_{\mathrm{M}}\right)$ values for the complexes are in the range of $0-6.82 \Omega^{-1} \mathrm{~cm}^{2} \mathrm{~mol}^{-1}$ suggesting the non-electrolytic nature of the complexes in solutions. The molar conductivity values for the metal complexes indicate the non-existence of free ions acting as electrolytes in the solution [21].

\section{Cytotoxicity study}

All nine compounds, BHA and $\mathrm{CH}_{3}-\mathrm{BHA}$ with their $\mathrm{VO}(\mathrm{IV}), \mathrm{Cr}(\mathrm{III})$ and $\mathrm{Ni}(\mathrm{II})$ complexes were evaluated for their biological activity, specifically cytotoxicity on colorectal carcinoma cell line (HCT116) as compared with standard, 5-fluorouracil. All tested compounds induced a concentration-dependent antiproliferative effect towards HCT116 cells upon treatment for 24 hours. All compounds are soluble in DMSO. $\mathrm{IC}_{50}$ values of $\mathrm{BHA}$ and $\mathrm{CH}_{3}$-BHA series against HCT116 cells are shown in Table 6.

Table 6. $\mathrm{IC}_{50}$ values of BHA and $\mathrm{CH}_{3} \mathrm{BHA}$ series on $\mathrm{HCT} 116$ cells

\begin{tabular}{lc}
\hline Ligands/Complexes & $\mathbf{I C}_{\mathbf{5 0}} \pm$ SD values $(\boldsymbol{\mu M})$ \\
\hline $\mathrm{BHA}$ & $>100$ \\
{$\left[\mathrm{VO}(\mathrm{BHA})_{2}\right]$} & $42.00 \pm 2.44$ \\
{$\left[\mathrm{Cr}(\mathrm{BHA})_{2}\left(\mathrm{H}_{2} \mathrm{O}\right)_{2}\right] \cdot \mathrm{H}_{2} \mathrm{O}$} & $>100$ \\
{$\left[\mathrm{Ni}(\mathrm{BHA})_{2}\left(\mathrm{H}_{2} \mathrm{O}\right)(\mathrm{OAc})\right]$} & $60.00 \pm 4.03$ \\
$\mathrm{CH}_{3}-\mathrm{BHA}$ & $>100$ \\
{$\left[\mathrm{VO}\left(\mathrm{CH}_{3}-\mathrm{BHA}\right)_{2}\right] \cdot \mathrm{H} 2 \mathrm{O}$} & $49.00 \pm 0.01$ \\
{$\left[\mathrm{Cr}\left(\mathrm{CH}_{3}-\mathrm{BHA}\right)_{2}\left(\mathrm{H}_{2} \mathrm{O}\right)_{2}\right] \cdot 2 \mathrm{H}_{2} \mathrm{O}$} & $>100$ \\
{$\left[\mathrm{Ni}\left(\mathrm{CH}_{3}-\mathrm{BHA}\right)_{2}\left(\mathrm{H}_{2} \mathrm{O}\right)_{2}\right] \cdot 2 \mathrm{H}_{2} \mathrm{O}$} & $40.00 \pm 3.11$ \\
Standard $(5-$ Fluorouracil $)$ & $13.07 \pm 0.00$ \\
\hline
\end{tabular}

[Ni( $\left.\left.\mathrm{CH}_{3}-\mathrm{BHA}\right)_{2}\right]$ display highest cytotoxicity activity among all tested compounds but considered as non-potent anticancer agents compared as 5-fluorouracil. $\mathrm{BHA}, \mathrm{CH}_{3}-\mathrm{BHA},\left[\mathrm{Cr}(\mathrm{BHA})_{2}\right] \cdot 3 \mathrm{H}_{2} \mathrm{O}$ and $\left[\mathrm{Cr}\left(\mathrm{CH}_{3}-\mathrm{BHA}\right)_{2}\right]$ display no inhibition towards HCT116. The ability of $\mathrm{CH}_{3}$ - $\mathrm{BHA}$ against cancer cells did not improve by the presence of electron donating group, $-\mathrm{CH}_{3}$ but it gives significant effects on improving the inhibition of $\mathrm{Ni}(\mathrm{II})$ complexes towards the cancer cells.

$\mathrm{VO}(\mathrm{IV})$ and $\mathrm{Ni}$ (II) complexes of BHA and $\mathrm{CH}_{3}$-BHA have better cytotoxicity compared to their free BHA and $\mathrm{CH}_{3}$-BHA. This observation can be explained by Tweedy's chelation theory and cell permeability by Overtone. Tweedy stated that complexation will lower the polarity of metal ions due to their positive charge to be shared with donor groups. It will make an increase of the delocalization of $\pi$-electrons over the entire chelate ring. Thus, this will enhance the lipophilicity of the complexes. According to Overtone's concept of cell permeability, the entry of any molecule into a cell is controlled by its lipophilicity because the lipid membrane that surrounds the cell favours the passage of materials that are soluble in lipids. Consequently, the increase of lipophilicity upon complexation enhances the penetration of the complexes into cells and will block the metal binding sites of receptors [22]. This explains why the $\mathrm{VO}$ (IV) and $\mathrm{Ni}(\mathrm{II})$ complexes give a better cytotoxicity than their parent ligands, BHA and $\mathrm{CH}_{3}$-BHA.

\section{Conclusion}

BHA and its derivative, $\mathrm{CH}_{3}$-BHA, and their metal complexes $\mathrm{VO}$ (IV), $\mathrm{Cr}$ (III) and $\mathrm{Ni}$ (II) have been successfully synthesized and characterized by elemental analysis, infrared spectroscopy, ${ }^{1} \mathrm{H}$ and ${ }^{13} \mathrm{C}$ NMR spectroscopy, 


\section{Latifah Robbaniyyah et al: SYNTHESIS AND CHARACTERIZATION OF BENZOHYDROXAMIC ACID AND METHYLBENZOHYDROXAMIC ACID METAL COMPLEXES AND THEIR CYTOTOXICTY STUDY}

UV $\square$ Visible, TGA, magnetic susceptibility as well as molar conductivity. From the spectral study, the ligands were indicated to have coordinated through oxygen and oxygen $(O, O)$ atoms to the metal center through bidentate manner. All complexes were paramagnetic except $\left[\mathrm{VO}(\mathrm{BHA})_{2}\right]$. [ $\left.\mathrm{VO}(\mathrm{BHA})_{2}\right]$ is diamagnetic suggesting the dimeric nature of this complex. All complexes were non-electrolyte. In concordance with the basic of chelation theory, metal complexes have shown higher toxicity against human colorectal cancer (HCT116) than their parent ligands, BHA and $\mathrm{CH}_{3}$-BHA. [Ni( $\mathrm{CH}_{3}$-BHA $)_{2}$ ] shows the highest cytotoxicity of $\mathrm{IC}_{50}$ values, $40.00 \mu \mathrm{M}$.

\section{Acknowledgement}

The authors would like to acknowledge the Ministry of Education of Malaysia for the research fund (RAGS/1/2015/ST0/UITM/03/1), Faculty of Applied Sciences, UiTM for research facilities and Faculty of Pharmacy, UiTM for the facilities on cytotoxicity study.

\section{References}

1. Kakkar, R. (2013). Theoretical studies on hydroxamic acids. In S. P. Gupta (Ed.), Hydroxamic Acids: A Unique Family of Chemicals with Multiple Biological Activities (pp. 21-47). Springer.

2. Marmion, Celine, J., Griffith, D. and Nolan, K. B. (2004). Hydroxamic acids - an intriguing family of enzyme inhibitors and biomedical ligands. European Journal of Inorganic Chemistry, 2004(15): 3003 -3016.

3. Sharma, N., Kumari, M., Kumar, V., Chaudhry, S. C. and Kanwar, S. S. (2010). Synthesis, characterization, and antibacterial activity of vanadium(iv) complexes of hydroxamic acids. Journal of Coordination Chemistry, 63(1): $176-184$.

4. Griffith, D., Krot, K., Comiskey, J., Nolan, K. B. and Marmion, C. J. (2008). Monohydroxamic acids and bridging dihydroxamic acids as chelators to ruthenium(III) and as nitric oxide donors: syntheses, speciation studies and nitric oxide releasing investigation. Dalton Transactions, (1): 137-147.

5. Farkas, E., Enyedy, É. A., Micera, G. and Garribba, E. (2000). Coordination modes of hydroxamic acids in copper(II), nickel(II) and zinc(II) mixed-ligand complexes in aqueous solution. Polyhedron, 19(14): 1727-1736.

6. Hazalin, N. A. M. N., Ramasamy, K., Lim, S. M., Wahab, I. A., Cole, A. L. J., Bakar, A., and Majeed, A. (2009). Cytotoxic and antibacterial activities of endophytic fungi isolated from plants at the National Park, Pahang, Malaysia. BMC Complementary and Alternative Medicine, 1-5.

7. Chauhan, D. S., Verma, K. K., and Garg, S. (2017). Synthesis, Characterization and antimicrobial studies on some pyridoxylidene - sulphamethoxazole Schiff base tellurium(IV) complexes. Der Pharma Chemica, 9(8): $59-64$.

8. Srivastava, K. P., Singh, B., and Akbar, A. (2009). Synthesis and characterisation of Co(II) complexes of dibasic tetradentate (oo' no donor) ligand. International Journal of ChemTech Research, 1(1): 71 -79.

9. Chauhan, S., Deepak, Garg, S., and Verma, K. K. (2016). Study on 4-methoxybenzohydroxamate complexes of aryltellurium (IV) and diaryltellurium (IV). International Journal of Chemical Sciences, 14(1): 269 - 282.

10. Yadava, A. K., Yadav, H. S., Singh, S., Yadav, U. S. and Rao, D. P. (2013). Synthesis and characterization of some novel Schiff Base complexes of oxovanadium(IV) cation. Journal of Chemistry, 2013: 1 - 5.

11. Haratake, M., Fukunaga, M., Ono, M. and Nakayama, M. (2005). Synthesis of Vanadium (IV, V) hydroxamic acid complexes and in vivo assessment of their insulin-like activity. Journal of Biological Inorganic Chemistry, 10(3): 250-258.

12. Griffith, D., Bergamo, A., Pin, S., Vadori, M., Muller-Bunz, H., Sava, G., and Marmion, C. J. (2007). Novel platinum pyridinehydroxamic acid complexes: Synthesis, characterisation, X-ray crystallographic study and nitric oxide related properties. Polyhedron, 26: $4697-4706$.

13. Pavia, D. L., Lampman, G. M., and Kriz, G. S. (2001). Introduction to Spectroscopy (Third ed.). United States of America: Brooks/Cole Thomson Learning: pp 310.

14. Naqeebullah, Farina, Y., Chan, K. M., Mun, L. K., Rajab, N. F., and Ooi, T. C. (2013). Diorganotin(IV) Derivatives of $n$-methyl $p$-fluorobenzo-hydroxamic acid: Preparation, spectral characterization, X-ray diffraction studies and antitumor activity. Molecules, 18(7): $8696-8711$.

15. Miessler, G. L., Fischer, P. J., and Tarr, D. A. (2014). Inorganic Chemistry (Fifth ed.). United States of America: Pearson: pp 359-361.

16. Saif, M., El-shafiy, H. F., Mashaly, M. M., Eid, M. F., Nabeel, A. I., and Fouad, R. (2016). Synthesis, characterization, and antioxidant/cytotoxic activity of new chromone Schiff base nano-complexes of $\mathrm{Zn}$ (II), $\mathrm{Cu}(\mathrm{II}), \mathrm{Ni}(\mathrm{II})$ and $\mathrm{Co}(\mathrm{II})$. Journal of Molecular Structure: $1-42$. 
17. Abu Bakar, S. N., Bahron, H., and Kassim, K. (2010). Synthesis and characterization of a novel Schiff base derived from 2,4,6-trimethyl-m-phenylenediamine with o-vanillin and its metal complexes. International Conference on Science and Social Research: pp. 463 - 466.

18. Aranha, P. E., dos Santos, M. P., Romera, S., and Dockal, E. R. (2006). Synthesis, characterization , and spectroscopic studies of tetradentate Schiff base chromium(III) complexes. Polyhedron, 26(7): 1373 - 1382.

19. Ahmed, A. A., BenGuzzi, S. A., and Ahshad, O. M. (2009). Synthesis and characterization of some vanadyl Schiff bases complexes. Rasayan Journal of Chemistry, 2(4), 781-785.

20. Mathew, N. (2011). Studies on metal complexes of some tridentate acylhydrazones. Dissertation of Doctor philosophy. Retrieved from http://hdl.handle.net/10603/6270.

21. Temel, H. (2014). Synthesis and spectroscopic studies of new $\mathrm{Cu}(\mathrm{II}), \mathrm{Ni}(\mathrm{II}), \mathrm{VO}(\mathrm{IV})$ and $\mathrm{Zn}(\mathrm{II})$ complexes with n,n'-bis(2-hydroxynaphthalin-1-carbaldehydene)-1,2-bis-(o-aminophenoxy)ethane. Journal of Coordination Chemistry, 57(9): 723 - 729.

22. Çıralıa, D. E., Uyar, Z., Koyuncu, İ., and Hacioğlu, N. (2015). Synthesis, characterization and catalytic , cytotoxic and antimicrobial activities of two novel cyclotriphosphazene-based multisite ligands and their $\mathrm{Ru}(\mathrm{II})$ complexes. Applied Organometallic Chemistry, 29: 536 - 542. 